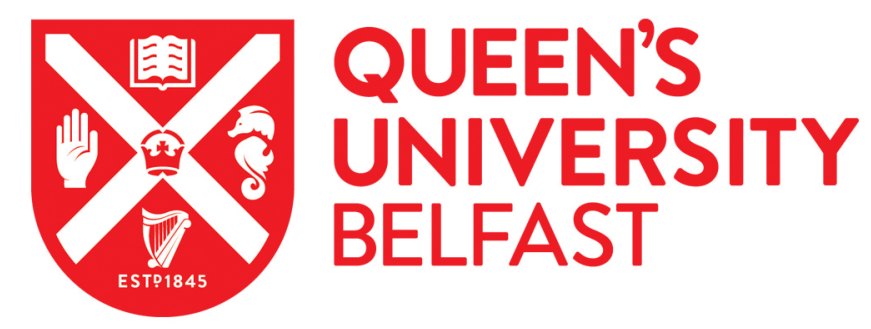

\title{
Ash from Changbaishan Millennium eruption recorded in Greenland ice: Implications for determining the eruption's timing and impact
}

Sun, C., Plunkett, G., Liu, J., Zhao, H., Sigl, M., McConnell, J. R., Pilcher, J. R., Vinther, B., Steffensen, J. P., \& Hall, V. (2014). Ash from Changbaishan Millennium eruption recorded in Greenland ice: Implications for determining the eruption's timing and impact. Geophysical Research Letters, 41(2), 694-701. https://doi.org/10.1002/2013GL058642

Published in:

Geophysical Research Letters

Document Version:

Publisher's PDF, also known as Version of record

Queen's University Belfast - Research Portal:

Link to publication record in Queen's University Belfast Research Portal

Publisher rights

(c) 2014. American Geophysical Union. All Rights Reserved.

\section{General rights}

Copyright for the publications made accessible via the Queen's University Belfast Research Portal is retained by the author(s) and / or other copyright owners and it is a condition of accessing these publications that users recognise and abide by the legal requirements associated with these rights.

Take down policy

The Research Portal is Queen's institutional repository that provides access to Queen's research output. Every effort has been made to ensure that content in the Research Portal does not infringe any person's rights, or applicable UK laws. If you discover content in the Research Portal that you believe breaches copyright or violates any law, please contact openaccess@qub.ac.uk. 


\section{Geophysical Research Letters}

\section{RESEARCH LETTER \\ 10.1002/2013GL058642 \\ Key Points: \\ - Tephra from Changbaishan \\ Millennium eruption is present in \\ Greenland ice \\ Ash from Changbaishan Millennium eruption recorded in Greenland ice: Implications for determining the eruption's timing and impact}

- Associated sulfate levels suggest eruption was not climatically effective

Supporting Information:

- Introduction: Tephra geochemical and ice core chemical analyses reported in this paper.

- Readme_final

Correspondence to:

G. Plunkett,

g.plunkett@qub.ac.uk

Citation:

Sun, C., G. Plunkett, J. Liu, H. Zhao, M. Sigl, J. R. McConnell, J. R. Pilcher, B. Vinther, J. P. Steffensen, and V. Hall (2014), Ash from Changbaishan Millennium eruption recorded in Greenland ice: Implications for determining the eruption's timing and impact, Geophys. Res. Lett., 41, doi:10.1002/ 2013 GL058642.

Received 8 NOV 2013

Accepted 28 DEC 2013

Accepted article online 5 JAN 2014

\section{Introduction}

\author{
Chunqing Sun ${ }^{1,2}$, Gill Plunkett ${ }^{3}$, Jiaqi Liu ${ }^{1}$, Hongli Zhao ${ }^{3}$, Michael Sigl ${ }^{4}$, Joseph R. McConnell ${ }^{4}$, \\ Jonathan R. Pilcher ${ }^{3}$, Bo Vinther ${ }^{5}$, J. P. Steffensen ${ }^{5}$, and Valerie Hall ${ }^{3}$
}

${ }^{1}$ Key Laboratory of Cenozoic Geology and Environment, Institute of Geology and Geophysics, Chinese Academy of Sciences, Beijing, China, ${ }^{2}$ Department of Earth Science, University of Chinese Academy of Sciences, Beijing, China, ${ }^{3}$ School of Geography, Archaeology and Palaeoecology, Queen's University Belfast, Belfast, UK, ${ }^{4}$ Desert Research Institute, Reno, Nevada, USA, ${ }^{5}$ Niels Bohr Institute, University of Copenhagen, Copenhagen, Denmark

Volcanic forcing of climate at subdecadal scales, mainly through stratospheric loading of sulfates and other aerosols and their impact on radiative balance, is well established through instrumental records of recent eruptions [McCormick et al., 1995; Fischer et al., 2007], although the precise mechanisms by which this is achieved remain uncertain [Driscoll et al., 2012]. Understanding the nature and causes of past climate change nevertheless requires that climate models factor in atmospheric loading of aerosols [Schmidt et al., 2012; Timmreck, 2012]. Polar ice cores provide the most important records of past volcanism for paleoclimate models through their acidity levels, chemistry and electrical conductivity, enabling stratospheric sulfate loading to be estimated [Robock and Free, 1995; Gao et al., 2008]. Neither the location nor the magnitude of a source eruption can be determined from ice core chemical records alone, however, as less climatically effective high-latitude eruptions can also contribute to the ice core acidity levels [Robock and Free, 1995]. Ash (tephra) particles in the ice, conversely, can provide evidence of the source eruption and greatly improve the interpretation of likely volcanic forcing.

Changbaishan Volcano (also known as Tianchi, Baitoushan, or Paektu) $\left(128^{\circ} 03^{\prime} \mathrm{E}, 42^{\circ} 00^{\prime} \mathrm{N}\right)$ is an intraplate stratovolcano located on the border between China and North Korea. A Plinian eruption around 1000 years ago (the "Millennium eruption") has been attributed a volcanic explosivity index of 7 based on an estimated $\sim 25-35 \mathrm{~km}$ high eruptive column and a total tephra volume of $\sim 100 \mathrm{~km}^{3}$ (magma volume (DRE $\sim 25 \mathrm{~km}^{3}$ )) [Horn and Schmincke, 2000; Wei et al., 2003]. Fine fallout from this eruption extended mainly to the east and east-northeast, as far as north Japan and Kuril trench $(>1000 \mathrm{~km})$, where a 2-10 cm thick deposit of ash has been recorded [Machida and Arai, 1983] (Figure 1). Modeling the radiative forcing of the eruption, Li et al. [1996] estimated an average Northern Hemisphere cooling of $0.85^{\circ} \mathrm{C}$ and a potential global climate impact extending over 6 years. Notwithstanding uncertainty regarding the eruption's atmospheric loading, estimates of halogen emissions based on petrological data indicate potential for stratospheric ozone depletion [Horn and Schmincke, 2000]; although sulfur release calculated by the same means was considerably less, the authors suggest that their data indicate a minimum output and hypothesize that the eruption was capable of a substantial but short-lived climatic impact. 

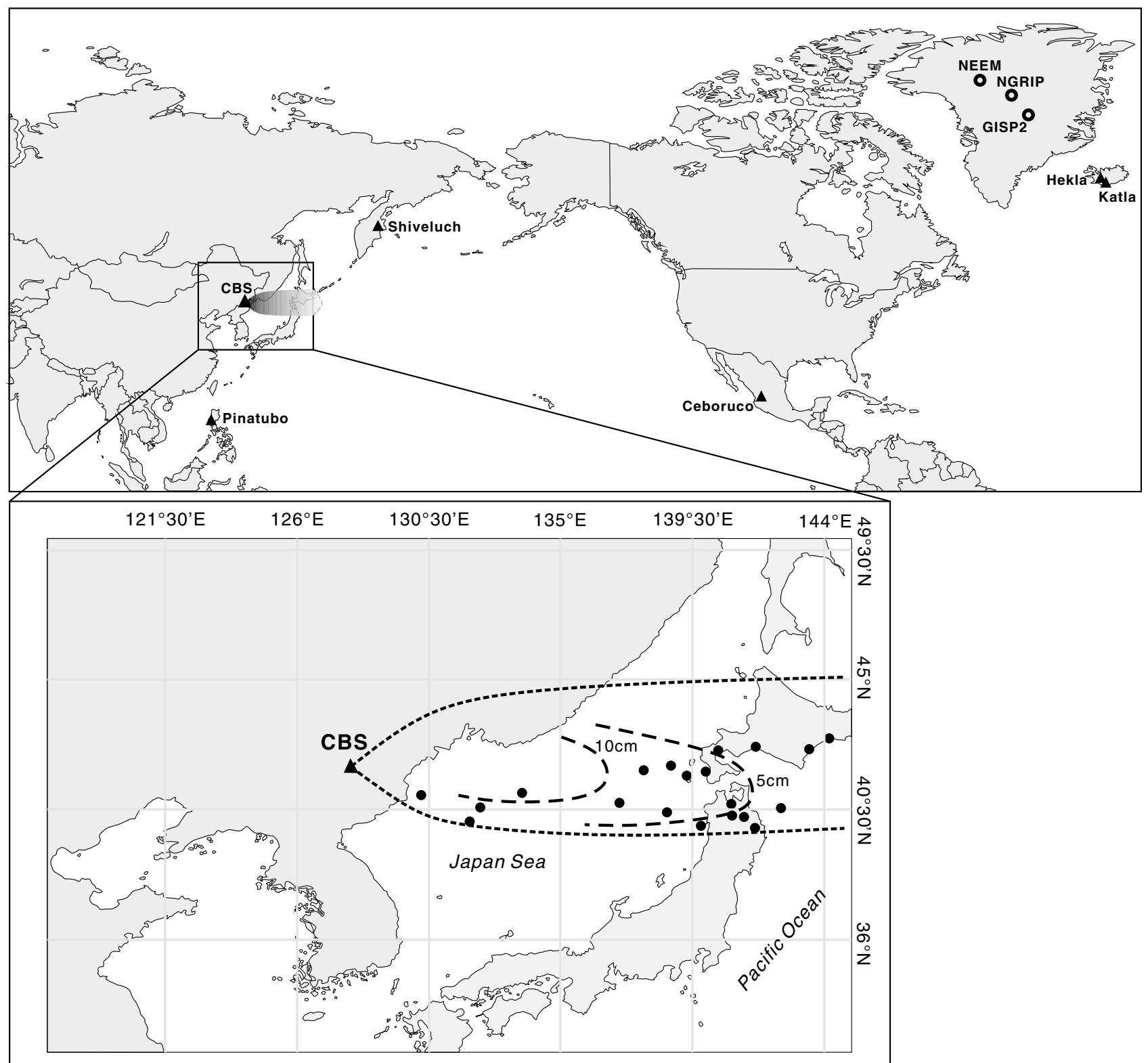

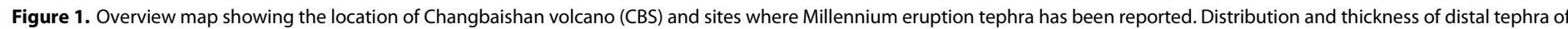

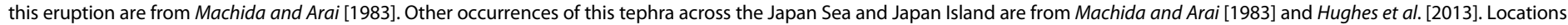
of Eldgjá (Katla), NGRIP, NEEM-2011-S1, and other sites mentioned in the text are marked.

No unambiguous historical records of this eruption have been found in China or North Korea [Machida et al., 1990]. The timing of the event was placed variably between the eighth and eleventh centuries according to conventional and wiggle match ${ }^{14} \mathrm{C}$ dating [e.g., Horn and Schmincke, 2000; Nakamura et al., 2007]. More recent studies have attempted to refine the dating of the eruption through ${ }^{14} \mathrm{C}$ wiggle matching of proximal timbers buried by pumice fallout or pyroclastic flow from the eruption and have proposed dates of A.D. 923-939 [Yin et al., 2012] and A.D. 940-952 [Xu et al., 2013]. Through consideration of contemporary records, and tree ring and Greenland ice core data, these studies have reached divergent conclusions regarding its impact.

Historical records and tree ring indices from northeast Asia and Europe are consistent with dust veil events and associated cooling at A.D. 933/934 and A.D. 939/940 in Europe and Asia, each of which has been regarded as possible evidence for a protracted climate impact triggered by the Eldgjá eruption in Iceland 
[Stothers, 1998; Fei et al., 2003]. Correlation of the weather anomalies with the Eldgjá event has, however, been complicated by subtle discrepancies in proposed ice core dates for the event. In the Greenland Ice Sheet Project 2 (GISP2) core, sulfate and chlorine spikes at A.D. $938 \pm 4$ (GISP2 chronology) have been firmly linked with Eldgjá through the identification of tephra shards in the ice [Zielinski et al., 1995]. Comparable aerosol spikes also attributed to the Eldgjá eruption in the Dye-3, GRIP, and North Greenland Ice Core Project (NGRIP) cores, on the other hand, are dated to A.D. $933 \pm 1$ (Greenland Ice Core Chronology 2005, GICC05) [Vinther et al., 2006].

Differences in the ice core chronologies relate to the perceived annual layer counting errors within the cores; both chronologies are precisely dated in the midfourteenth century A.D. through the presence of tephra from Öraefajökull A.D. 1362 eruption [Palais et al., 1991; Coulter et al., 2012] and are further cross-matched using distinctive acid signals attributed to the historically dated Hekla A.D. 1104 and Vesuvius A.D. 79 events [Zielinski, 1996; Vinther et al., 2006]. Barbante et al. [2013] have recently reported the identification of Vesuvius tephra in the GRIP ice core 1 year prior to the acid signal. Between these marker horizons, however, cumulative layer counting errors may exist and chronological precision is not absolute. Furthermore, sampling resolution in the GISP2 core is biennial, and this is factored into the dating error [Zielinski et al., 1994].

For most researchers, subdecadal chronological imprecision is almost negligible, but for the correlation of ice core records to annually resolved or historical records, it can be critical, and the ice core volcanic record of the midtenth century A.D. is a case in point. Accepting the GICC05 age (A.D. $933 \pm 1$ ) for the Eldgjá eruption, Yin et al. [2012] argue for a second climatically effective event in that decade and suggest that documented weather and tree ring anomalies at A.D. 939/940 correlate with their proposed date of A.D. 938/9 for the Millennium eruption. Conversely, Xu et al. [2013] favor the GISP2 midpoint date of A.D. 938 for the Eldgjá eruption and point to the absence of a sulfate spike and concomitant cooling in the GISP2 record in the period A.D. 940-952 to which they date the Millennium eruption; on this basis, they suggest that the Millennium eruption had a low sulfur injection into the stratosphere and that it thus had a negligible climate impact.

Recent research on the NGRIP ice core reported a bimodal population of unprovenanced tephra (QUB-1437) dated by GICC05 to A.D. 940-941 \pm 1 [Coulter et al., 2012]. Here we demonstrate that this tephra correlates on major element geochemistry with glass from the Millennium eruption, and we report the finding of the same tephra in the new NEEM-2011-S1 ice core from northern Greenland. Our results enable the possible atmospheric loading, and by extrapolation the climatic effectiveness, of the event to be evaluated critically.

\section{Methods}

The extraction and electron probe single-shard analysis of the NGRIP tephra QUB-1437 was described by Coulter et al. [2012]. On the basis of the sulfate record, three consecutive samples of NEEM-2011-S1 ice were cut from each of the intervals spanning A.D. 939-942 and A.D. 932-935 (GICC05 timescale) at the Desert Research Institute (DRI), Reno, and transferred to individual Nalgene bottles (supporting information). The meltwater was evaporated on frosted microprobe slides in a laminar flow cupboard at Queen's University Belfast (QUB), and the dry residues were covered with Buehler EpoxiCure resin. Tephra shards were quantified at 100X-400X magnification using a polarizing light microscope. Samples of white-yellow, grey, and black fallout pumice were collected from vertical exposures on the Korean flank of the Tianchi crater, reflecting progressive changes in the geochemical composition of the fallout; subsamples were mounted onto microprobe slides and covered with Buehler epoxy resin [Zhao, 2010]. Slides bearing tephra were ground with $12 \mu \mathrm{m}$ alumina and polished with $6 \mu \mathrm{m}, 3 \mu \mathrm{m}$, and $1 \mu \mathrm{m}$ diamond paste to expose the surfaces of shards (distal material) or glass matrix (proximal material). The slides were carbon coated and glass composition was analyzed using the JEOL FEG-SEM microprobe at QUB under the same operating conditions as QUB-1437 [Coulter et al., 2012]. A single analysis from one sample was obtained using the Cameca SX-100 at the University of Edinburgh (see supporting information for operating conditions). Secondary glass standards were measured at each analytical session to ensure instrument precision and accuracy (supporting information). Data have been normalized to $100 \%$ on a volatile- and water-free basis for plotting and statistical comparisons. Similarity coefficients for the tephras and possible correlates were calculated on the basis of major element analyses that comprised $>1 \%$ concentration of the tephras, following Borchardt et al. [1972].

Procedures for the measurement of sulfate in NGRIP are described in Coulter et al. [2012] and the same methods were used to measure chloride. For NEEM-2011-S1, total sulfur, chlorine, and sodium concentrations 


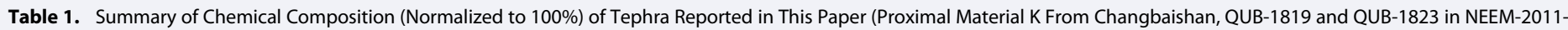

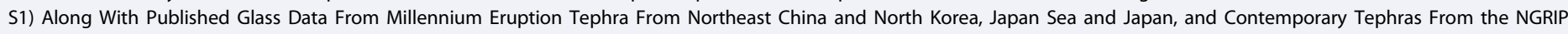
(QUB-1437) and GISP2 (Glass B) Greenland Ice Cores

\begin{tabular}{|c|c|c|c|c|c|c|c|c|c|c|c|c|c|c|}
\hline & Sample & $\mathrm{SiO}_{2}$ & $\mathrm{TiO}_{2}$ & $\mathrm{Al}_{2} \mathrm{O}_{3}$ & $\mathrm{FeO}$ & $\mathrm{MnO}$ & $\mathrm{MgO}$ & $\mathrm{CaO}$ & $\mathrm{Na}_{2} \mathrm{O}$ & $\mathrm{K}_{2} \mathrm{O}$ & $\mathrm{P}_{2} \mathrm{O}_{5}$ & $\mathrm{Cl}$ & Analytical Total & \\
\hline \multirow[t]{8}{*}{ Changbaishan volcano } & $\mathrm{K}-\mathrm{a}(n=6)$ & 67.94 & 0.36 & 14.61 & 4.58 & - & 0.13 & 1.09 & 5.51 & 5.78 & - & - & 95.99 & Mean \\
\hline & & 1.31 & 0.15 & 0.47 & 0.39 & - & 0.14 & 0.36 & 0.14 & 0.15 & - & - & 0.50 & $2 S D$ \\
\hline & $\mathrm{K}-\mathrm{b}(n=10)$ & 74.88 & 0.20 & 10.66 & 4.05 & 0.08 & 0.02 & 0.26 & 5.32 & 4.52 & - & - & 96.34 & Mean \\
\hline & & 0.53 & 0.07 & 0.36 & 0.19 & 0.10 & 0.03 & 0.07 & 0.68 & 0.19 & - & - & 0.72 & $2 S D$ \\
\hline & $\mathrm{TC}-\mathrm{a}(n=3)^{\mathrm{a}}$ & 67.00 & 0.46 & 15.16 & 4.89 & 0.10 & 0.13 & 1.11 & 5.27 & 5.87 & - & - & & Mean \\
\hline & & 1.33 & 0.12 & 0.55 & 0.25 & 0.11 & 0.08 & 0.17 & 0.46 & 0.32 & - & - & & $2 S D$ \\
\hline & TC-b $(n=15)^{\mathrm{a}}$ & 74.58 & 0.25 & 10.90 & 4.20 & 0.07 & 0.06 & 0.28 & 5.01 & 4.66 & - & - & & Mean \\
\hline & & 3.75 & 0.10 & 2.19 & 0.44 & 0.06 & 0.10 & 0.35 & 0.61 & 0.78 & - & - & & $2 S D$ \\
\hline \multirow[t]{4}{*}{ Japan region } & B-Tm-a $(n=18)^{\mathrm{a}}$ & 66.63 & 0.46 & 14.86 & 5.01 & 0.14 & 0.24 & 1.36 & 5.67 & 5.42 & - & - & & Mean \\
\hline & & 2.48 & 0.39 & 1.00 & 0.67 & 0.20 & 0.42 & 0.88 & 0.64 & 0.41 & - & - & & $2 S D$ \\
\hline & B-Tm-b $(n=24)^{\mathrm{a}}$ & 74.79 & 0.24 & 10.53 & 4.19 & 0.10 & 0.03 & 0.28 & 5.07 & 4.37 & - & - & & Mean \\
\hline & & 1.94 & 0.17 & 1.04 & 0.32 & 0.10 & 0.07 & 0.16 & 0.54 & 0.47 & - & - & & $2 S D$ \\
\hline \multirow[t]{4}{*}{ NGRIP } & QUB-1437a $(n=10)^{\mathrm{b}}$ & 68.05 & 0.30 & 14.86 & 4.80 & 0.14 & 0.12 & 1.26 & 4.69 & 5.76 & - & - & 95.77 & Mean \\
\hline & & 2.14 & 0.13 & 0.89 & 0.30 & 0.16 & 0.11 & 0.32 & 0.58 & 0.47 & - & - & 1.56 & $2 S D$ \\
\hline & QUB-1437b $(n=6)^{\mathrm{b}}$ & 75.58 & 0.20 & 10.41 & 4.18 & 0.08 & 0.04 & 0.29 & 4.57 & 4.65 & - & - & 96.42 & Mean \\
\hline & & 2.87 & 0.12 & 0.76 & 0.23 & 0.09 & 0.07 & 0.35 & 1.22 & 0.43 & - & - & 1.17 & $2 S D$ \\
\hline \multirow[t]{7}{*}{ NEEM-2011-S1 } & QUB-1819a $(n=6)$ & 67.63 & 0.39 & 14.78 & 4.77 & 0.17 & 0.11 & 1.12 & 5.36 & 5.48 & & 0.18 & 96.58 & Mean \\
\hline & & 1.50 & 0.02 & 0.97 & 0.42 & 0.19 & 0.08 & 0.36 & 0.86 & 0.36 & & 0.08 & 1.86 & $2 S D$ \\
\hline & QUB-1819b $(n=4)$ & 74.74 & 0.22 & 10.57 & 4.07 & 0.04 & 0.02 & 0.29 & 5.04 & 4.54 & 0.00 & 0.46 & 96.18 & Mean \\
\hline & & 0.90 & 0.06 & 1.02 & 0.44 & 0.04 & 0.02 & 0.19 & 1.01 & 0.52 & & 0.05 & 4.82 & $2 S D$ \\
\hline & QUB-1819c $(n=1)$ & 76.53 & 0.06 & 13.34 & 0.57 & 0.08 & 0.03 & 0.81 & 3.79 & 4.70 & - & 0.08 & 94.91 & \\
\hline & QUB-1823a $(n=1)$ & 71.29 & 0.46 & 14.91 & 2.17 & 0.08 & 0.40 & 1.57 & 2.71 & 3.72 & - & 0.13 & 92.49 & \\
\hline & QUB-1823b $(n=1)$ & 77.94 & 0.02 & 13.49 & 0.51 & 0.19 & 0.05 & 0.78 & 4.04 & 4.74 & - & 0.11 & 94.23 & \\
\hline \multirow[t]{2}{*}{ GISP2 } & Glass B $(n=9)^{c}$ & 69.2 & 1.3 & 13.5 & 5.3 & 0 & 1.1 & 3.2 & 2.9 & 3.6 & & & & Mean \\
\hline & & 1.8 & 0.2 & 1.1 & 0.8 & & 0.4 & 0.6 & 1.1 & 0.5 & & & & SD \\
\hline
\end{tabular}

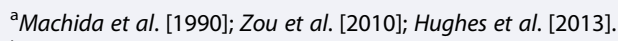

${ }^{\mathrm{b}}$ Coulter et al. [2012].

'Zielinski [1996].

were measured simultaneously using a continuous flow analysis system coupled to two inductively coupled plasma-mass spectrometers with an effective sampling resolution of $\sim 1 \mathrm{~cm}$ [McConnell et al., 2002]. Analyses were performed using $1 \mathrm{~m}$ longitudinal samples $(30 \times 30 \mathrm{~mm})$ at the Ultra Trace Chemistry Laboratory at DRI. Non-sea-salt sulfur (nssS) concentrations were calculated from total sulfur concentrations using coregistered sodium concentrations as a sea-salt tracer and assuming a sulfur to sodium ratio in bulk seawater of 0.084 (i.e., [nssS] $=[\mathrm{S}]-0.084[\mathrm{Na}]$ ). Here we report data from a secondary independent reanalysis of NEEM-2011-S1 (performed between A.D. 900 and 1130) for which the analytical setup was set to achieve increased depth resolution. Volcanic sulfate flux extraction follows procedures described by Sigl et al. [2013] with extracted deposition fluxes for volcanic events reproducing those from the primary analysis. The timescale was derived by annual layer counting constrained by volcanic signals [Sigl et al., 2013] identified in the NGRIP ice core record on the GICC05 timescale [Vinther et al., 2006].

\section{Results}

Tephra shards were identified in NEEM-2011-S1 samples dating to A.D. 940.5-941.4 (QUB-1819) and A.D. 933.8-934.5 (QUB-1823) (GICC05 chronology). QUB-1819 is characterized by mainly platy, colorless shards, the majority of which are less than $\sim 10 \mu \mathrm{m}$ in size; at least 30 shards between 10 and $50 \mu \mathrm{m}$ in size were recorded (see supporting information for light microscope photographs). Analyses with acceptable analytical totals (>94\%) were obtained from 10 shards. QUB-1823 contained only two shards, one a blocky, colorless shard $(13 \times 35 \mu \mathrm{m})$ and the other, small $(10 \times 6 \mu \mathrm{m})$ and slightly vesicular. Analytical totals were low $(92-94 \%)$ for each shard but the results are sufficiently distinct to warrant reporting.

The results from QUB-1819 and QUB-1823 are summarized in Table 1 along with newly analyzed proximal material from Tianchi (K), QUB-1437 from NGRIP, published proximal and distal data from Millennium eruption deposits in NE China and Japan (TC, B-Tm), and the dacitic component (Glass B) found with Eldgjá basaltic tephra in GISP2 (see supporting information for full data sets and similarity coefficients). The proximal and distal Millennium eruption glass data indicate a bimodal (rhyolitic and trachytic) magmatic composition that is clearly distinct from other contemporary large Northern Hemisphere eruptions (Figure 2); of particular note is that the ratio of $\mathrm{FeO}_{\mathrm{t}}$ to $\mathrm{CaO}$ in the Millennium eruption magma is greater than in products from other 


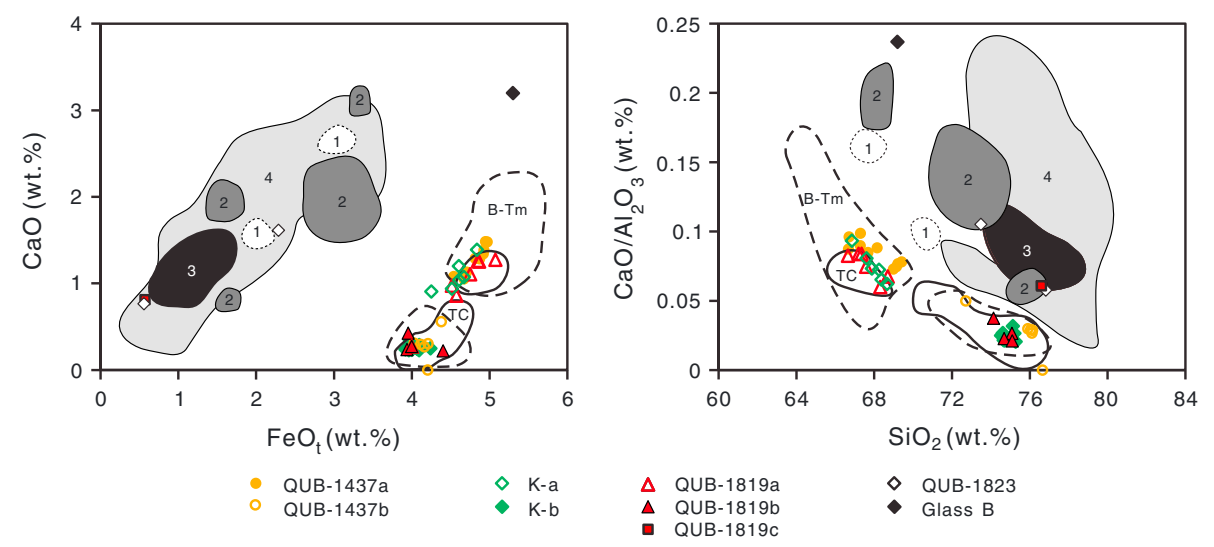

Figure 2. Binary plots demonstrating major element chemical similarity of glass shards from Greenland ice cores with both proximal (Changbaishan volcano) and distal (Japan areas) deposits of the Millennium eruption tephra. Glass compositions of K, QUB-1437, QUB1819a, and QUB-1819b are comparable to those of published proximal and distal data produced by the Millennium eruption and clearly distinct from broadly contemporary eruptions with similar compositions, such as (1) the Jala pumice of Volcán Ceboruco, Mexico [Gardner and Tait, 2000], (2) Hekla A.D. 1104 (data from http://www.tephrabase.org/; sources Boygle [1994]; Larsen et al. [1999]), (3) Holocene tephra of Shiveluch volcano, Russia [Ponomareva et al., 2007], and (4) widespread Quaternary tephra around Japan [Aoki and Machida, 2006] and the dacitic Glass B in GISP2 at A.D. $938 \pm 4$ [Zielinski et al., 1995] (envelopes represent distribution of published data points). Published B-Tm and TC data are from Machida et al. [1990]; Zou et al. [2010], and Hughes et al. [2013], and QUB-1437 data are from Coulter et al. [2012]. QUB-1823 is clearly distinct from GISP2 Glass B.

volcanic regions. QUB-1437 and QUB-1819 reveal the same distinctive bimodal character, and provide compelling evidence for the arrival of Millennium eruption ash in Greenland. QUB-1819 also contains an outlying analysis (QUB-1819c) characterized by a low iron and lesser alkali content that is not consistent with volcanic products from Iceland, Kamchatka, or China (G. Larsen, personal communication; V. Ponomareva, personal communication, 2013). The two shards from QUB-1823 are also bimodal, and do not correlate with Eldgjá, GISP2 Glass B, or any other Icelandic eruption at this time. Their provenance is not currently known. The rhyolitic shard (QUB-1823b) is, however, comparable in major element composition to QUB-1819c.

\section{Discussion}

Our tephra results from NEEM-2011-S1 do not enable us to confirm that the A.D. 933-934 (GICC05) acid spike was the result of the Eldgjá eruption, but given the petrological data from Eldgjá deposits [Thordarson et al., 2001] and the similarities in the chemical records between GISP2 and other Greenland ice cores, it is reasonable to argue that this event at least partly (and perhaps mainly) contributed to the volcanic signal in Greenland ice at A.D. 933/934 (GICC05) or A.D. 938/939 (GISP2 chronology). In the absence of a tephrochronological confirmation of a common source of these acid layers, the exceptional high chlorine concentrations accompanying the volcanic signal provides an additional stratigraphic link between the three ice core records, as well as with the Dye-3 and GRIP ice cores [Clausen et al., 1997]. Nevertheless, the analyses from QUB-1823 raise the possibility that one or more other eruptions also occurred at this time and, notwithstanding uncertainty regarding the event's precise date, may have augmented the climate impact inferred from historical records [Stothers, 1998; Fei et al., 2003].

The unambiguous presence of Millennium eruption tephra in NGRIP and NEEM-2011-S1 enables a precise correlation of the event with synchronous, short-lived (<1 year) sulfate spikes at A.D. $941 \pm 1$ (GICC05), and clearly places the eruption $\sim 7$ years after the acid peak (sulfate and chlorine) attributed to Eldgjá (Figure 3). In addition, the strong seasonality expressed in the natural background of the plotted chlorine/chloride data provides a means to visualize the data underlying the annual layer counting in NGRIP and NEEM-2011-S1 and supports our attributed age offset of $\sim 7$ years between the Eldgjá and Millennium eruptions. The apparent absence of an acid signal in GISP2 in the A.D. $940 \mathrm{~s}$ may be due to the lower resolution ( 2 years) of this core's data over this interval [Zielinski et al., 1994]. The Millennium eruption is thus dated to either $\sim$ A.D. $941 \pm 1$ (GICC05) or A.D. $945 \pm 4$ (GISP2 chronology), and within the dating error of the ice core chronologies is unlikely to have occurred any earlier than the winter of A.D. 939/940. Ostensibly, historical observations consistent with a large regional eruption-unusual sonic effects ("thunders like a drum") in Japan and Korea 

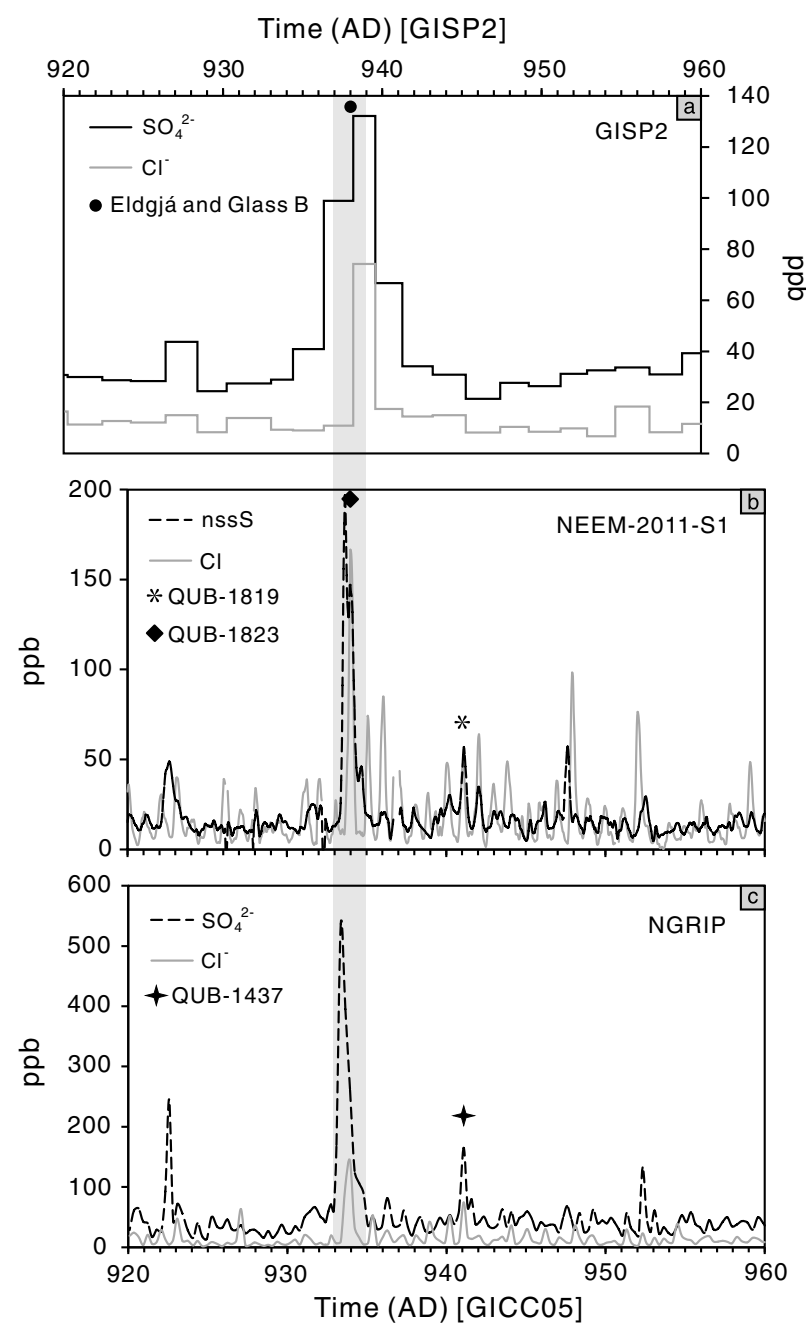

Figure 3. Cross comparison of chemical data from NGRIP, NEEM-2011-S1, and GISP2 ice cores for the period A.D. 920-960: (a) total sulfate and chloride concentrations in GISP2, (b) non-sea-salt sulfur and chlorine concentrations in NEEM-2011-S1, and (c) total sulfate and chloride concentrations in NGRIP. Plots are aligned on the basis of the common volcanic signal attributed to the Eldgjá eruption (grey band). GISP2 data are from http://www.ncdc.noaa.gov/paleo/icecore/greenland/summit/document/gispdata.htm. NGRIP sulfate data are from Coulter et al. [2012], converted to $\mathrm{ppb}$ scale. Sampling resolution of GISP2 is biennial and NGRIP is four samples a year ( $5 \mathrm{~cm}$ resolution). NEEM-2011-S1 resolution is 20 samples per year ( $1 \mathrm{~cm}$ resolution). NGRIP and NEEM data from the sections shown are provided in supporting information.

and "white ash rain" in Japan in the winter of A.D. 946-7 [Xu et al., 2013] —favor the later, GISP2 age estimate. Uncertainty regarding the precision of the ice core chronologies prohibits a definitive linkage or distinction of the event from historically recorded and tree ring dated events. Nevertheless, the potential climate impact of the eruption can be assessed using aerosol data from the ice cores.

QUB-1437 and QUB-1819 are each directly associated with distinct peaks in volcanic sulfates (Figure 3). In NEEM2011-S1, QUB-1819 and a sulfur spike occur amidst an enhanced volcanic signal beginning 2 years prior to the Millennium tephra level, suggesting that more than one eruption is recorded in the ice at this time, a prospect supported by the outlying shard QUB-1819c. The coeval deposition of Millennium eruption tephra and aerosols over Greenland implies rapid initial transport to the ice sheet through a common tropospheric or stratospheric pathway. The dispersal pattern of the Millennium eruption tephra [Machida and Arai, 1983] also indicates predominant east-northeastward upper winds during this eruption (Figure 1) that would have favored rapid transport of ash and aerosols toward Greenland within weeks or months of the eruption. Sulfate deposition estimates at this time are in the order of $11 \mathrm{~kg} \mathrm{~km}^{-2}$ in NGRIP and $13 \mathrm{~kg} \mathrm{~km}^{-2}$ in NEEM-2011-S1 [Sigl et al., 2013]. The higher resolved sulfate record from NEEM-2011-S1 deployed for this study further suggest that $9 \mathrm{~kg} \mathrm{~km}^{-2}$ were deposited during the peak associated with tephra (247.29-247.13 m) while an additional $4 \mathrm{~kg} \mathrm{~km}^{-2}$ were 
deposited during the earlier event. These levels are considerably less than the estimated deposition following eruptions such as Tambora $1815\left(\sim 40 \mathrm{~kg} \mathrm{~km}^{-2}\right)$ or Krakatau $1883\left(\sim 15-18 \mathrm{~kg} \mathrm{~km}^{-2}\right)$ but are consistent with the modest, petrologically estimated sulfur output calculated by Horn and Schmincke [2000] for the Millennium eruption. We conclude, therefore, that the stratospheric loading from this event is unlikely to have been sufficient to impact significantly on extraregional climate. Furthermore, growth-ring data from trees killed by the fallout deposits indicate that the eruption occurred sometime between autumn and spring [Yin et al., 2012], when the climate impact of eruptions in higher latitudes may be negligible [Kravitz and Robock, 2011].

\section{Conclusions}

Tephra and chemical analyses from the NGRIP and NEEM-2011-S1 Greenland ice cores have enabled an assessment of the likely atmospheric aerosol loading of the Millennium eruption and an evaluation of the extraregional climate impact of the event. Although the eruption was sufficiently powerful to disperse tephra to northern Greenland, associated non-sea-salt sulfur and sulfate concentrations are low and short-lived. This finding suggests that the eruption would not have had any substantial climate impact. The exact timing of the eruption remains ambiguous because the ice core chronologies are not absolutely dated at this time but in light of the relatively low sulfate loading from the event as well as an expected time lag in European climate response to volcanic forcing [Esper et al., 2013], weather anomalies across Eurasia in A.D. 939-940 (mainly concentrated in Europe) are unlikely to be the result of this eruption. On the basis of a stratigraphic ( 7 years) offset, we can nevertheless distinguish the Millennium eruption from the major Eldgjá eruption which remains a contender for a volcanic source of the climate perturbations at A.D. 939-940.

\section{Acknowledgments}

Collection of samples at Changbaishan was supported by the China NFS grants (41272369 and 40930314), and we thank H. He, Z. Guo, and other colleagues for their help in the field. Chris Hayward kindly provided support on the CAMECA SX100 microprobe. We are grateful to Guðrún Larsen and Vera Ponomareva for their comments on the tephra results. We thank the 109th New York Air National Guard for airlift to and from Greenland. We also appreciate the assistance of the NEEM community for logistics, drilling, science, and other support. In particular, we thank S.-B. Hansen, T. Popp, D. Mandeno, M. Leonhardt, and A. Moy for drilling the NEEM-2011-S1 core. Analysis and interpretation of the NEEM-2011-S1 ice core at DRI was funded by NSF grant 9090541. We acknowledge N. Chellman, L. Layman, O. Maselli, and D. Pasteris for their assistance in the lab.

The Editor thanks Clive Oppenheimer and an anonymous reviewer for their assistance in evaluating this paper.

\section{References}

Aoki, K., and H. Machida (2006), Major element composition of volcanic glass shards in the late Quaternary widespread tephras in JapanDistinction of tephras using $\mathrm{K}_{2} \mathrm{O}-\mathrm{TiO}_{2}$ diagrams, Bull. Geol. Surv. Jpn., 57, 239-258.

Barbante, C., N. M. Kehrwald, P. Marianelli, B. M. Vinther, J. P. Steffensen, G. Cozzi, C. U. Hammer, H. B. Clausen, and M.-L. Siggaard-Andersen (2013), Greenland ice core evidence of the 79 AD Vesuvius eruption, Clim. Past, 9, 1221-1232, doi:10.5194/cp-9-1221-2013.

Borchardt, G., P. Aruscavage, and H. J. Millard (1972), Correlation of the Bishop ash, a Pleistocene marker bed, using instrumental neutron activation analysis, J. Sediment. Res., 42, 301-306, doi:10.1306/74D72527-2B21-11D7-8648000102C1865D.

Boygle, J. E. (1994), Tephra in lake sediments: An unambiguous geochronological marker?, PhD thesis, University of Edinburgh, Edinburgh, U K.

Clausen, H. B., C. U. Hammer, C. S. Hvidberg, D. Dahl-Jensen, J. P. Steffensen, J. Kipfstuhl, and M. Legrand (1997), A comparison of the volcanic records over the past 4000 years from the Greenland Ice Core Project and Dye 3 Greenland Ice Cores, J. Geophys. Res., 102, 26,707-26,723.

Coulter, S. E., J. R. Pilcher, G. Plunkett, M. Baillie, V. A. Hall, J. P. Steffensen, B. M. Vinther, H. B. Clausen, and S. J. Johnsen (2012), Holocene tephras highlight complexity of volcanic signals in Greenland ice cores, J. Geophys. Res., 117, D21303, doi:10.1029/2012JD017698.

Driscoll, S., A. Bozzo, L. J. Gray, A. Robock, and G. Stenchikov (2012), Coupled Model Intercomparison Project 5 (CMIP5) simulations of climate following volcanic eruptions, J. Geophys. Res., 117, D17105, doi:10.1029/2012JD017607.

Esper, J., L. Schneider, P. J. Krusic, J. Luterbacher, U. Büntgen, M. Timonen, F. Sirocko, and E. Zorita (2013), European summer temperature response to annually dated volcanic eruptions over the past nine centuries, Bull. Volcanol., 75, 736-750, doi:10.1007/s00445-013-0736-z.

Fei, J., J. Zhou, Y. Hou, and Z. An (2003), Chinese historical records of the climatic impact of 934 AD Eldgjá eruption in Iceland, Global Geol., 22, 214-225.

Fischer, E. M., J. Luterbacher, E. Zorita, S. F. B. Tett, C. Casty, and H. Wanner (2007), European climate response to tropical volcanic eruptions over the last half millennium, J. Geophys. Res., 34, L05707, doi:10.1029/2006GL027992.

Gao, C., A. Robock, and C. Ammann (2008), Volcanic forcing of climate over the past 1500 years: An improved ice-core-based index for climate models, J. Geophys. Res., 113, D23111, doi:10.1029/2008JD010239.

Gardner, J. E., and S. Tait (2000), The caldera-forming eruption of Volcán Ceboruco, Mexico, Bull. Volcanol., 62, 20-33, doi:10.1007/ s004450050288.

Horn, S., and H.-U. Schmincke (2000), Volatile emission during the eruption of Baitoushan Volcano (China/North Korea) ca. 969 AD, Bull. Volcanol., 61, 537-555, doi:10.1007/s004450050004.

Hughes, P. D. M., G. Mallon, A. Brown, H. J. Essex, J. D. Stanford, and S. Hotes (2013), The impact of high tephra loading on late-Holocene carbon accumulation and vegetation succession in peatland communities, Quat. Sci. Rev., 67, 160-175, doi:10.1016/j. quascirev.2013.01.015.

Kravitz, B., and A. Robock (2011), Climate effects of high-latitude volcanic eruptions: Role of the time of year, J. Geophys. Res., 116, D01105, doi:10.1029/2010JD014448.

Larsen, G., A. J. Dugmore, and A. J. Newton (1999), Geochemistry of historic silicic tephras in Iceland, Holocene, 9, 463-471, doi:10.1191/ 095968399669624108.

Li, X., M. Li, and R. Liu (1996), The climate effects of the Changbaishan-Tianchi volcano eruption, Seismol. Geomagnetic Observation Res., 17, 12-18.

Machida, H., and F. Arai (1983), Extensive ash falls in and around the sea of Japan from large late Quaternary eruptions, J. Volcanol. Geotherm. Res., 18, 151-164, doi:10.1016/0377-0273(83)90007-0.

Machida, H., H. Moriwaki, and D. Zhao (1990), The recent major eruption of Changbai volcano and its environmental effects, Geogr. Rep Tokyo Metrop. Univ., 25, 1-20.

McConnell, J. R., G. W. Lamorey, S. W. Lambert, and K. C. Taylor (2002), Continuous ice-core chemical analyses using inductively coupled plasma mass spectrometry, Environ. Sci. Technol., 36, 7-11, doi:10.1021/es011088z. 
McCormick, M. P., L. W. Thomason, and C. R. Trepte (1995), Atmospheric effects of the Mt Pinatubo eruption, Nature, 373, 399-404, doi:10.1038/373399a0.

Nakamura, T., et al. (2009), Application of ${ }^{14} \mathrm{C}$ wiggle-matching to support dendrochronological analysis in Japan, Tree Ring Res., 63, 37-46, doi:10.3959/1536-1098-63.1.37.

Palais, J. M., K. Taylor, P. A. Mayewski, and P. Grootes (1991), Volcanic ash from the 1362 A.D. Oræfajokull eruption (Iceland) in the Greenland ice sheet, Geophys. Res. Lett., 18, 1241-1244, doi:10.1029/91GL01557.

Ponomareva, V., P. Kyle, M. Pevzner, L. Sulerzhitsky, and M. Hartman (2007), Holocene eruptive history of Shiveluch Volcano, Kamchatka Peninsula, Russia, in Volcanism and Subduction: The Kamchatka Region, Geophys. Monogr. Ser., vol. 172, edited by J. Eichelberger et al., pp. 263-282, AGU, Washington, D. C., doi:10.1029/172GM19.

Robock, A., and M. P. Free (1995), Ice cores as an index of global volcanism from 1850 to the present, J. Geophys. Res., 100, 11,549-11,567, doi:10.1029/95JD00825.

Schmidt, G. A., et al. (2012), Climate forcing reconstructions for use in PMIP simulations of the Last Millennium (v1.1), Geosci. Model Dev., 5, 185-191, doi:10.5194/gmd-5-185-2012.

Sigl, M., et al. (2013), A new bipolar ice core record of volcanism from WAIS Divide and NEEM and implications for climate forcing of the last 2000 years, J. Geophys. Res. Atmos., 118, 1151-1169, doi:10.1029/2012JD018603.

Stothers, R. B. (1998), Far reach of the tenth century Eldgjá eruption, Iceland, Clim. Change, 39, 715-726, doi:10.1023/A:1005323724072.

Thordardson, T., D. J. Miller, G. Larsen, S. Self, and H. Sigurdsson (2001), New estimates of sulphur degassing and atmospheric mass-loading by the 934 AD Eldgjá eruption, Iceland, J. Volcanol. Geothermal Res., 108, 33-54, doi:110.1016/\$0377-0273(00)00277-8.

Timmreck, C. (2012), Modeling the climatic effects of large explosive volcanic eruptions, WIREs Clim. Change, 3, 545-564, doi:10.1002/wcc.192.

Vinther, B. M., et al. (2006), A synchronised dating of three Greenland ice cores throughout the Holocene, J. Geophys. Res., 111, D13102, doi:10.1029/2005JD006921.

Wei, H., et al. (2003), Three active volcanoes in China and their hazards, J. Asian Earth Sci., 21, 515-526, doi:10.1016/S1367-9120(02)00081-0.

Xu, J., B. Pan, T. Liu, I. Hajdas, B. Zhao, H. Yu, R. Liu, and P. Zhao (2013), Climatic impact of the millennium eruption of Changbaishan volcano in China: New insights from high-precision radiocarbon wiggle-match dating, Geophys. Res. Lett., 40, 54-59, doi:10.1029/2012GL054246.

Yin, J., A. J. T. Jull, G. S. Burr, and Y. Zheng (2012), A wiggle-match age for the Millennium eruption of Tianchi Volcano at Changbaishan, Northeastern China, Quat. Sci. Rev., 47, 150-159, doi:10.1016/j.quascirev.2012.05.015.

Zhao, H. (2010), Quaternary distal tephra studies of northeastern China, PhD thesis, Queen's University Belfast, Belfast, U K.

Zielinski, G. A. (1996), Stratospheric loading and optical depth estimates of explosive volcanism over the last 2100 years derived from the Greenland Ice Sheet Project 2 ice core, J. Geophys. Res., 100, 20,937-20,955, doi:10.1029/95JD01751.

Zielinski, G. A., P. A. Mayewski, L. D. Meeker, S. Whitlow, M. S. Twickler, M. Morrison, D. A. Meese, A. J. Gow, and R. B. Alley (1994), Record of volcanism since 7000 B.C. from GISP2 Greenland ice core and implications for the volcano-climate system, Science, 264, 948-952, doi:10.1126/science.264.5161.948.

Zielinski, G. A., M. S. Germani, G. Larsen, M. G. L. Baillie, S. Whitlow, M. S. Twickler, and K. Taylor (1995), Evidence of the Eldgjá (Iceland) eruption in the GISP2 Greenland ice core: Relationship to eruption processes and climate conditions in the tenth century, Holocene, 5 , 129-140, doi:10.1177/095968369500500201.

Zou, H., Q. Fan, and H. Zhang (2010), Rapid development of the great Millennium eruption of Changbaishan (Tianchi) Volcano, China/North Korea: Evidence from U-Th zircon dating, Lithos, 119, 289-296, doi:10.1016/j.lithos.2010.07.006. 